\title{
Characterization of a combined batch-continuous procedure for the culture of anammox biomass
}

\author{
Romain Connan ${ }^{\mathrm{a}}$, Patrick Dabert ${ }^{\mathrm{a}}$, Sophie Le Roux ${ }^{\mathrm{a}}$, Olivier Chapleur ${ }^{\mathrm{b}}$, Gilbert Bridoux ${ }^{\mathrm{c}}$, \\ Matias B. Vanotti ${ }^{\mathrm{d}}$, Fabrice Béline ${ }^{\mathrm{a}}$, Albert Magrí ${ }^{\mathrm{a}, *}$ \\ a Irstea, UR OPAALE, 17 Avenue de Cucillé-CS 64427, F-35044 Rennes, France \\ b Irstea, UR HBAN, 1 rue Pierre-Gilles de Gennes-CS 10030, F-92761 Antony Cedex, France \\ ' SAUR, Recherche et développement, 2 rue de la Bresle, F-78201 Maurepas, France \\ d USDA-ARS Coastal Plains Soil, Water and Plant Research Center, 2611 W. Lucas St., Florence, SC 29501, USA
}

\begin{abstract}
Interest in autotrophic nitrogen $(\mathrm{N})$ removal through anaerobic ammonium oxidation (anammox) is high in the field of wastewater treatment as a more economic and sustainable alternative than con-ventional nitrification-denitrification. However, anammox biomass is difficult to enrich, and this can hinder the start-up of new applications. We carried out experimental work to characterize a combined batch-continuous procedure for the enrichment and culture of anammox biomass. In the first stage (time span: $120 \mathrm{~d}$ ), the enrichment was started in batch mode (sealed vial) using suspended activated sludge as inoculum. Anammox activity was clearly developed since the specific ammonium $\left(\mathrm{NH}_{4}^{+}\right)$conversion rate increased from 0 to $118 \pm 1$ mg NH${ }_{4}^{+}-$ $\mathrm{N} /(\mathrm{g} \mathrm{VS} \mathrm{d}$ ) (VS, volatile solids); i.e., $560 \pm 11 \mathrm{mg} \mathrm{N} /(\mathrm{L} \mathrm{d}$ ) in terms of N-conversion rate (NCR). Subsequently, the sludge was transferred into a continuous upflow reactor packed with a polyester non-woven material to promote the attached growth of the biomass. Such bioreactor was operated without interruption during $400 \mathrm{~d}$. Under an appropriate feeding regime, the anammox activity increased fast, and a sustained NCR of $1183 \pm 100 \mathrm{mg} \mathrm{N} /(\mathrm{L} \mathrm{d}) \mathrm{was}$ reached according to the N-loading rate applied. Evolution of the microbial community structure was characterized using high-throughput DNA sequencing. The overall procedure prompted the selection of a community enriched in the anammox bacterial species Candidatus Brocadia sinica (up to $\sim 70 \%$ of the total DNA sequences). Other coexisting microbial groups belonged to Rhodocyclaceae (class $\beta$-Proteobacteria), Anaerolineae (phylum Chloroflexi) and Ignavibacteriaceae (phylum Chlorobi).
\end{abstract}

\section{Introduction}

The anaerobic ammonium oxidation (anammox) is an interesting bioprocess for the removal of nitrogen $(\mathrm{N})$ from wastewaters

\footnotetext{
Abbreviations: anammox, anaerobic ammonium oxidation; DO, dissolved oxygen; HRT, hydraulic residence time; N, nitrogen; NCE, nitrogen conversion efficiency; NCR, nitrogen conversion rate; NLR, nitrogen loading rate; NMDS, nonmetric multidimensional scaling; OTU, operational taxonomic unit; PCR, polymerase chain reaction; SBR, sequencing batch reactor; VS, volatile solids; WWTP, wastewater treatment plant.

* Corresponding author at: Institut national de Recherche en Sciences et Technologies pour l'Environnement et l'Agriculture (Irstea), 17 Avenue de Cucillé - CS 64427, F-35044 Rennes, France.

E-mail addresses: connan.romain@gmail.com (R. Connan), patrick.dabert@irstea.fr (P.Dabert),sophie.leroux@irstea.fr

(S. Le Roux), olivier.chapleur@irstea.fr (O. Chapleur), gbridoux@saur.fr(G. Bridoux), matias.vanotti@ars.usda.gov (M.B. Vanotti), fabrice.beline@irstea.fr (F. Béline), albert.magri@gmail.com (A. Magrí).
}

since it allows more economic and sustainable treatment than conventional approaches based on heterotrophic denitrification (Ma et al., 2016; Siegrist et al., 2008). In engineered systems, its coupling with partial nitritation results in a complete autotrophic deammonification, which reduces by $60 \%$ the oxygen requirement, $100 \%$ the organic carbon requirement, and $90 \%$ the biosolids production with respect to classical nitrification-denitrification. In addition, it offers the chance of working with more compact reactors at higher loading rates (Magrí et al., 2013; Van Hulle et al., 2010).

The anammox process is mediated by chemolithoautotrophic bacteria that oxidize ammonium $\left(\mathrm{NH}_{4}{ }^{+}\right)$into dinitrogen gas $\left(\mathrm{N}_{2}\right)$ using nitrite $\left(\mathrm{NO}_{2}{ }^{-}\right)$as the electron acceptor (Strous et al., 1998). Nitric oxide (NO) and hydrazine $\left(\mathrm{N}_{2} \mathrm{H}_{4}\right)$ are two known intermediates of such reaction (Kartal et al., 2011). This bioconversion takes place under absence of oxygen and presence of inorganic carbon. A small amount of nitrate $\left(\mathrm{NO}_{3}{ }^{-}\right)$is also produced due to the oxidation of nitrite linked to the fixation of inorganic carbon in anabolism (de Almeida et al., 2011). According to the full stoichiometry pro- 
posed by Strous et al. (1998) -Eq. (1)-, ammonium and nitrite are converted into dinitrogen gas and nitrate under the molar ratios 1.00/1.32/1.02/0.26 for $\mathrm{NH}_{4}{ }^{+}$consumption, $\mathrm{NO}_{2}{ }^{-}$consumption, $\mathrm{N}_{2}$ production, and $\mathrm{NO}_{3}{ }^{-}$production, respectively -values obtained through mass balance in a sequencing batch reactor (SBR) running under stable conditions-.

$$
\begin{aligned}
& 1.00 \mathrm{NH}_{4}{ }^{+}+1.32 \mathrm{NO}_{2}{ }^{-}+0.066 \mathrm{HCO}_{3}{ }^{-}+0.13 \mathrm{H}^{+} \\
& \rightarrow 1.02 \mathrm{~N}_{2}+0.26 \mathrm{NO}_{3}{ }^{-}+0.066 \mathrm{CH}_{2} \mathrm{O}_{0.5} \mathrm{~N}_{0.15}+2.03 \mathrm{H}_{2} \mathrm{O}
\end{aligned}
$$

To date, six "Candidatus" anammox bacterial genera have been enriched from samples collected in wastewater treatment facilities and natural environments such as freshwater and marine zones; i.e., Ca. Brocadia (Strous et al., 1999), Ca. Kuenenia (Schmid et al., 2000), Ca. Scalindua (Kuypers et al., 2003), Ca. Anammoxoglobus (Kartal et al., 2007), Ca. Jettenia (Quan et al., 2008), and Ca. Anammoximicrobium (Khramenkov et al., 2013). All these genera belong to the same phylum Planctomycetes. In spite of this fact, while the first five aforementioned genera form a deeply branched monophyletic group (family Brocadiaceae), the sixth is closely related to the genus Pirellula (family Planctomycetaceae). In physiological terms, the anammox bacteria feature a specific cytoplasmatic membrane-bound organelle known as anammoxosome, which is the locus of the anammox catabolism (van Niftrik and Jetten, 2012). They are also characterized by a low growth rate, with doubling times (at $\sim 30^{\circ} \mathrm{C}$ ) of $2.1-11$ days (Lotti et al., 2015; Strous et al., 1998). Owing to this slow biomass development and the specialized metabolism, the anammox bacteria may be difficult to culture.

The anammox bacteria have not been isolated in pure culture yet. Otherwise, such microorganisms have been enriched from various environments up to a culture purity degree of about $80-95 \%$ (van Niftrik and Jetten, 2012) -maximum value found in the literature is $98 \pm 1 \%$ in a suspended cell anammox culture (Lotti et al., 2014)-. Frequently, those strategies used to enrich anammox biomass consist on the utilization of different types of continuously operated reactors such as the SBR, rotating biological contactor, membrane bioreactor, upflow anaerobic sludge blanket reactor, upflow fixed-bed biofilm reactor, or stirred-tank moving-packedbed reactor, among others (Egli et al., 2003; Strous et al., 1998; Tsushima et al., 2007; Wang et al., 2009; Xiong et al., 2013; Bae et al., 2015). Alternatively, anammox enrichments have also been performed in batch mode using sealed vials (Bae et al., 2010; Connan et al., 2016; Yasuda et al., 2011). In all cases, appropriate selection of the environmental conditions such as temperature, $\mathrm{pH}$, and levels of ammonium, nitrite, organic carbon, dissolved oxygen (DO), and other nutrients and inhibitors, is critical for a successful enrichment and mass culture (Carvajal-Arroyo et al., 2013). The enrichment of anaerobic ammonium-oxidizing biomass from conventional sludge is time-consuming and may take from several months to years depending on the seeding source, reactor setup, and operational conditions applied (Ibrahim et al., 2016). Thus, biomass enrichment usually is the critical step for the start-up of new anammox applications (especially when pre-enriched sludge is not available).

The objective of this study is to characterize a culture of anammox biomass obtained from activated sludge using a combination of batch and continuous procedures. The enrichment was started under suspended biomass batch mode (sealed vial) and subsequently continued using a continuous upflow reactor packed with a polyester non-woven material to promote the attached growth of the biomass. The evolution of the microbial community structure was characterized throughout the process by means of 16S rRNA gene high-throughput sequencing.

\section{Material and methods}

\subsection{Biomass sources: collection and pretreatment}

Activated sludge collected in a municipal wastewater treatment plant (WWTP) that combine the use of a Modified Ludzack-Ettinger bioreactor unit and a membrane filtration loop to perform $\mathrm{N}$ removal was used as inoculum for the enrichment of anammox biomass. Such treatment facility is located in Betton (France). Before starting with the anammox enrichment procedure, denitrification was favored during the first days after sampling in order to promote biodegradation of residual organic matter. Such pretreatment was carried out at room temperature by adding a nitrate source $\left(\mathrm{KNO}_{3}\right)$ in pulses equivalent to $100 \mathrm{mg} \mathrm{N} / \mathrm{L}$, similarly to Casagrande et al. (2011), and controlling the pH within the range 7.0-8.0 $(\mathrm{HCl})$. The anammox batch enrichment was started after 4 weeks, once denitrification activity decreased. For microbial characterisation purposes, an alternative anammox biomass sample was obtained from a lab-scale $10 \mathrm{~L}$ jacketed upflow fixed-bed biofilm reactor running at the USDA-ARS laboratory in Florence, South Carolina, USA (Vanotti et al., 2011). At the time of sludge collection, the reactor was fed with mineral medium containing $153 \mathrm{mg} \mathrm{NH}_{4}{ }^{+}-\mathrm{N} / \mathrm{L}$ and $153 \mathrm{mg} \mathrm{NO}_{2}{ }^{-} \mathrm{N} / \mathrm{L}$, and was operated with a hydraulic residence time (HRT) of $4 \mathrm{~h}, \mathrm{~N}$-loading rate (NLR) of about $1800 \mathrm{mg} \mathrm{N} /(\mathrm{Ld})$ and water temperature of $30^{\circ} \mathrm{C}$, analogously as detailed by Magrí et al. (2012b). Once received at the Irstea laboratory in Rennes, the external sample (E) was stored for 2 years under freezing conditions before proceeding with DNA extraction.

\subsection{Batch stage}

The enrichment in batch mode was performed using a glass vial which contained the inoculum and mineral medium (working volume of $0.5 \mathrm{~L}$ ). Such vial was sealed with a rubber stopper plus an aluminium cap and placed into an incubator shaker (model KS4000i control, IKA, Germany) at $150 \mathrm{rpm}, 35^{\circ} \mathrm{C}$, and in dark conditions. Initial solids content inside the vial was adjusted to $1.50 \mathrm{~g} \mathrm{VS}$ (VS, volatile solids). Biomass settling was allowed weekly to withdrawn the supernatant and, subsequently, to refill the vial with new mineral medium (avoiding the eventual accumulation of inhibitory compounds). The mineral medium was initially prepared with low amount of nitrite and ammonium $\left(25 \mathrm{mg} \mathrm{NO}_{2}{ }^{-} \mathrm{N} / \mathrm{L}+25 \mathrm{mg} \mathrm{NH}_{4}{ }^{+}\right.$ $\mathrm{N} / \mathrm{L}$ ). Once the anammox activity was detected, a second weekly addition of nitrogenous substrates was performed targeting a progressive increase in the concentration of nitrite from 25 to $150 \mathrm{mg}$ $\mathrm{NO}_{2}{ }^{-} \mathrm{N} / \mathrm{L}$ (ammonium was added at a ratio of $1.2 \mathrm{~g} \mathrm{NO}_{2}{ }^{-} \mathrm{N} / \mathrm{g}$ $\mathrm{NH}_{4}{ }^{+}-\mathrm{N}$ ). The $\mathrm{pH}$ within the vial was controlled in the range from 7.0 to $8.0(\mathrm{HCl} 2 \mathrm{M}) \cdot \mathrm{N}_{2}$ flushing was used to displace air in the vial headspace every time it was opened. Liquid samples were taken before and after each feeding event and filtered using $0.45 \mu \mathrm{m}$ polypropylene membrane filters. A biological sample was taken once per month (B0-B4), centrifuged at $10,000 \mathrm{~g}$ for $4 \mathrm{~min}$, and the pellet was stored at $-20^{\circ} \mathrm{C}$ (after discarding the supernatant). This enrichment step lasted 120 days (4 months), and final anammox activity was evaluated in a batch test (in duplicates), as described elsewhere (Connan et al., 2016).

\subsection{Continuous stage}

The biomass enriched following the aforementioned method was seeded in a continuous upflow column reactor $(0.94 \mathrm{~g}$ VS). This was a jacketed cylindrical reactor made of glass (Trallero \& Schlee, Spain) with inner diameter of $9 \mathrm{~cm}$ and column height (to the effluent port) of $66 \mathrm{~cm}$. Similarly to other works (Furukawa et al., 2003; Vanotti et al., 2011), a support made of polyester non-woven material coated with pyridinium-type polymer (Japan Vilene Co., Japan) 
was placed inside the column reactor to enhance the retention of the biomass ( 8 strips each one $4.5 \mathrm{~cm}$ wide and $57 \mathrm{~cm}$ long). Total liquid volume was $4.5 \mathrm{~L}$ whereas volume of the reaction zone (excluding the upper $9 \mathrm{~cm}$ zone without support) was $3.9 \mathrm{~L}$. Process temperature was controlled at $35^{\circ} \mathrm{C}$ using a water heating circulator (model EH-13, Julabo, Germany). Mineral medium was continuously pumped inside the reactor by the bottom-end through a low-flow peristaltic pump (model PD5001, Heidolph, Germany) equipped with a multichannel head (model C4, Heidolph), and treated liquid was discharged near the top of the reactor after passing through the matrix of immobilized biomass. Targeted NLRs ranged from 111 to $1551 \mathrm{mg} \mathrm{N} /(\mathrm{Ld})$ according to the nominal volumetric flow rate $(3-12 \mathrm{~mL} / \mathrm{min})$ and influent concentration (50-175 $\mathrm{mg} \mathrm{NO}_{2}{ }^{-} \mathrm{N} / \mathrm{L}$ at a ratio of $\left.1 \mathrm{~g} \mathrm{NO}_{2}{ }^{-} \mathrm{N} / \mathrm{g} \mathrm{NH}{ }_{4}{ }^{+}-\mathrm{N}\right)$. Corresponding HRTs (taking into account the reaction volume) were 21.7-5.4 h. The mineral medium was stored at room temperature in a polyethylene tank sealed at the top to prevent air from entering (a Tedlar gas sampling bag filled with $\mathrm{N}_{2}$ was connected with tubing to the top of the tank). Such influent tank was refilled weekly with fresh mineral medium. Tygon tubing was used for the setup. The reactor was placed in a dark chamber to avoid light. Liquid samples were regularly taken from the influent and the effluent lines for chemical analysis. Volumetric flow rate was measured by collecting the liquid in a graduated cylinder during a known period of time. When required, gas samples were taken from the headspace of the reactor for analysis. Off-gas flow rate in the effluent line was measured using the water displacement method. Finally, biological samples from the reactor -considering bottom ("B") and top ("T") ends of the fabric material- were taken during the experimental period at time $0,3.5,6.5$, and 13.5 months (C0-C3X, where X corresponds to the letter "B" or "T"), and processed as aforementioned in Section 2.2. The upflow reactor was uninterruptedly operated during 400 days (13.5 months).

\subsection{Mineral medium}

The synthetic nutritive solution used throughout the experiments was prepared with tap water according to a modification of the mineral medium described by Magrí et al. (2012a); i.e., $\mathrm{NH}_{4} \mathrm{Cl}$ (variable: $95-669 \mathrm{mg} / \mathrm{L}$ ), $\mathrm{NaNO}_{2}$ (variable: $123-862 \mathrm{mg} / \mathrm{L}$ ), $\mathrm{KNO}_{3}$ (variable: $0-361 \mathrm{mg} / \mathrm{L}$ ), $\mathrm{KHCO}_{3}$ (variable: $0-1000 \mathrm{mg} / \mathrm{L}$ ), $\mathrm{NaHCO}_{3}$ (variable: $0-1000 \mathrm{mg} / \mathrm{L}$ ), $\mathrm{KH}_{2} \mathrm{PO}_{4}$ (variable: $0-27 \mathrm{mg} / \mathrm{L}$ ), $\mathrm{FeSO} 4.7 \mathrm{H}_{2} \mathrm{O}(9 \mathrm{mg} / \mathrm{L})$, EDTA $(5 \mathrm{mg} / \mathrm{L}), \mathrm{MgSO}_{4} \cdot 7 \mathrm{H}_{2} \mathrm{O}(240 \mathrm{mg} / \mathrm{L})$, $\mathrm{CaCl}_{2} \cdot 2 \mathrm{H}_{2} \mathrm{O}(143 \mathrm{mg} / \mathrm{L})$, and trace element solution $0.3 \mathrm{~mL} / \mathrm{L}$. The trace element solution contained $\mathrm{ZnSO}_{4} \cdot 7 \mathrm{H}_{2} \mathrm{O}(1247 \mathrm{mg} / \mathrm{L})$, $\mathrm{MnSO}_{4} \cdot \mathrm{H}_{2} \mathrm{O}(1119 \mathrm{mg} / \mathrm{L}), \mathrm{CuSO}_{4} \cdot 5 \mathrm{H}_{2} \mathrm{O}(44 \mathrm{mg} / \mathrm{L}), \mathrm{Al}_{2}\left(\mathrm{SO}_{4}\right)_{3} \cdot 14 \mathrm{H}_{2} \mathrm{O}$ (201.5 mg/L), $\mathrm{Na}_{2} \mathrm{MoO}_{4} \cdot 2 \mathrm{H}_{2} \mathrm{O}(129 \mathrm{mg} / \mathrm{L}), \mathrm{CoCl}_{2} \cdot 6 \mathrm{H}_{2} \mathrm{O}(30 \mathrm{mg} / \mathrm{L})$, $\mathrm{KCl}(100 \mathrm{mg} / \mathrm{L})$, and EDTA $(975 \mathrm{mg} / \mathrm{L}) . \mathrm{KNO}_{3}$ was added to the mineral medium throughout the batch enrichment period in order to help maintaining anoxic conditions in case of total nitrite consumption (preventing sulfate reduction). Unfortunately, because of a mislabeling by the chemical supplier $\left(\mathrm{K}_{2} \mathrm{O}\right.$ was supplied instead of $\mathrm{KH}_{2} \mathrm{PO}_{4}$ ) any phosphorus source was added to the mineral medium used during the batch enrichment and also during the first 90 days of operation of the upflow reactor. In this regard, during batch culture, phosphorus released by the decaying biomass seemed to be sufficient to avoid limitation in the availability of this nutrient. Conversely, this was not the case when operating the upflow reactor as it will be discussed later in Section 3.2.1. Once identified after analysis, the aforementioned chemical was replaced by a real source of $\mathrm{KH}_{2} \mathrm{PO}_{4}$. Finally, the liquid flow regime in the upflow reactor was assessed by punctually replacing the bicarbonate source in the mineral medium $\left(\mathrm{KHCO}_{3}\right.$ and $\mathrm{NaHCO}_{3}$ were interchanged $)$ and subsequently monitoring the evolution of the concentration of the potassium $\left(\mathrm{K}^{+}\right)$and sodium $\left(\mathrm{Na}^{+}\right)$ions in the effluent line. Once dis- solved all the mineral salts, the DO was purged by bubbling with $\mathrm{N}_{2}\left(<0.2 \mathrm{mg} \mathrm{O}_{2} / \mathrm{L}\right)$ and the $\mathrm{pH}$ was adjusted to $6.8-7.0(\mathrm{HCl})$.

\subsection{Chemical analysis}

$\mathrm{NH}_{4}^{+}, \mathrm{NO}_{2}{ }^{-}, \mathrm{NO}_{3}{ }^{-}, \mathrm{K}^{+}, \mathrm{Na}^{+}$, and phosphate $\left(\mathrm{PO}_{4}\right)$ were measured by ion chromatography (model 850 Professional IC, Metrohm, Switzerland). VS were measured after sample drying to constant weight at $105^{\circ} \mathrm{C}$ and further ignition in a muffle furnace at $550^{\circ} \mathrm{C}$. The $\mathrm{pH}$ and DO were measured using portable meters $\mathrm{pH} 197 \mathrm{i}$ and Oxi 197 (WTW, Germany), respectively. Nitrous oxide $\left(\mathrm{N}_{2} \mathrm{O}\right)$ in gaseous samples was measured by gas chromatography (model $6890 \mathrm{~N}$, Agilent Technologies, USA).

\subsection{N-transformation calculations}

Both, the N-conversion rate (NCR) and the N-conversion efficiency (NCE) were defined according to the removal of ammonium and nitrite from the liquid. During batch enrichment, the NCR was calculated from the corresponding time-dependent slopes for the evolution of the concentrations (obtained through linear regression analysis). Specific activity (specific-NCR) was determined taking into account the VS content in the vial. Under continuous operation of the upflow reactor, the NCR was calculated from the difference in concentrations between the influent and the effluent, divided by the measured HRT. Similarly, the NCE was calculated from the difference in concentrations between the influent and the effluent, divided by the total concentration in the influent. On the other hand, reaction molar ratios were calculated according to the difference in concentrations of ammonium, nitrite, and nitrate between influent and effluent and expressed per unit of ammonium removal. The dinitrogen gas reaction ratio was calculated through mass balance ( $1 \mathrm{~mol} \mathrm{~N}_{2}=2$ atoms $\mathrm{N}$ ) considering the other three measured $\mathrm{N}$-species.

\subsection{Microbial community analysis}

\subsubsection{DNA extraction}

Total DNA was extracted from approximately $0.25 \mathrm{~g}$ of pellet with the PowerSoil ${ }^{\mathrm{TM}}$ DNA Isolation Kit (MoBio Laboratories Inc., USA), according to the manufacturer's instructions. The concentration and purity of the extracted DNA were checked spectrophotometrically (model ND-1000, NanoDrop Technologies, USA) and in TAE $1 \mathrm{X}-0.7 \%$ agarose gel. The extracted DNA was stored at $-20^{\circ} \mathrm{C}$ until further analysis.

\subsubsection{High-throughput DNA sequencing}

16S rRNA genes high-throughput DNA sequencing was performed by the BIOMIC team of Irstea (Antony, France) using an Ion PGM $^{\mathrm{TM}}$ (Life Technologies, USA) platform, as described by Poirier et al. (2016a, 2016b). Briefly, the bacterial and archaeal hypervariable region V4-V5 of the 16S rRNA gene was amplified using the primer 515F (5'-GTGYCAGCMGCCGCGGTA-3') and a modified version of the primer 928R (Wang and Qian, 2009) that was named 928Ramx (5'-CCCCGYCAATTCHTTTRAGT-3'). The primer 928Ramx includes the nucleotide $\mathrm{H}$ ( T, A or $\mathrm{C}$ ) instead of the nucleotide $\mathrm{M}$ ( $\mathrm{A}$ or $C$ ) in position 13 , which does not change its universality but increases its similarity with anammox sequences. Amplification was performed in a $50 \mu \mathrm{L}$ reaction mixture using from 10 to $200 \mathrm{pg}$ of extracted DNA and the Pfx SuperMix protocol from Life Technologies, as described in Poirier et al. (2016b). Further processing of the polymerase chain reaction (PCR) products - purification, quantification, emulsion PCR, and sequencing on an Ion $316^{\mathrm{TM}}$ chip v2 using the Ion PGM ${ }^{\mathrm{TM}}$ System (Life Technologies)- was carried out according to the manufacturer's instructions, as described in Connan et al. (2016). After sequencing, the $\mathrm{PGM}^{\mathrm{TM}}$ software filtered out low 


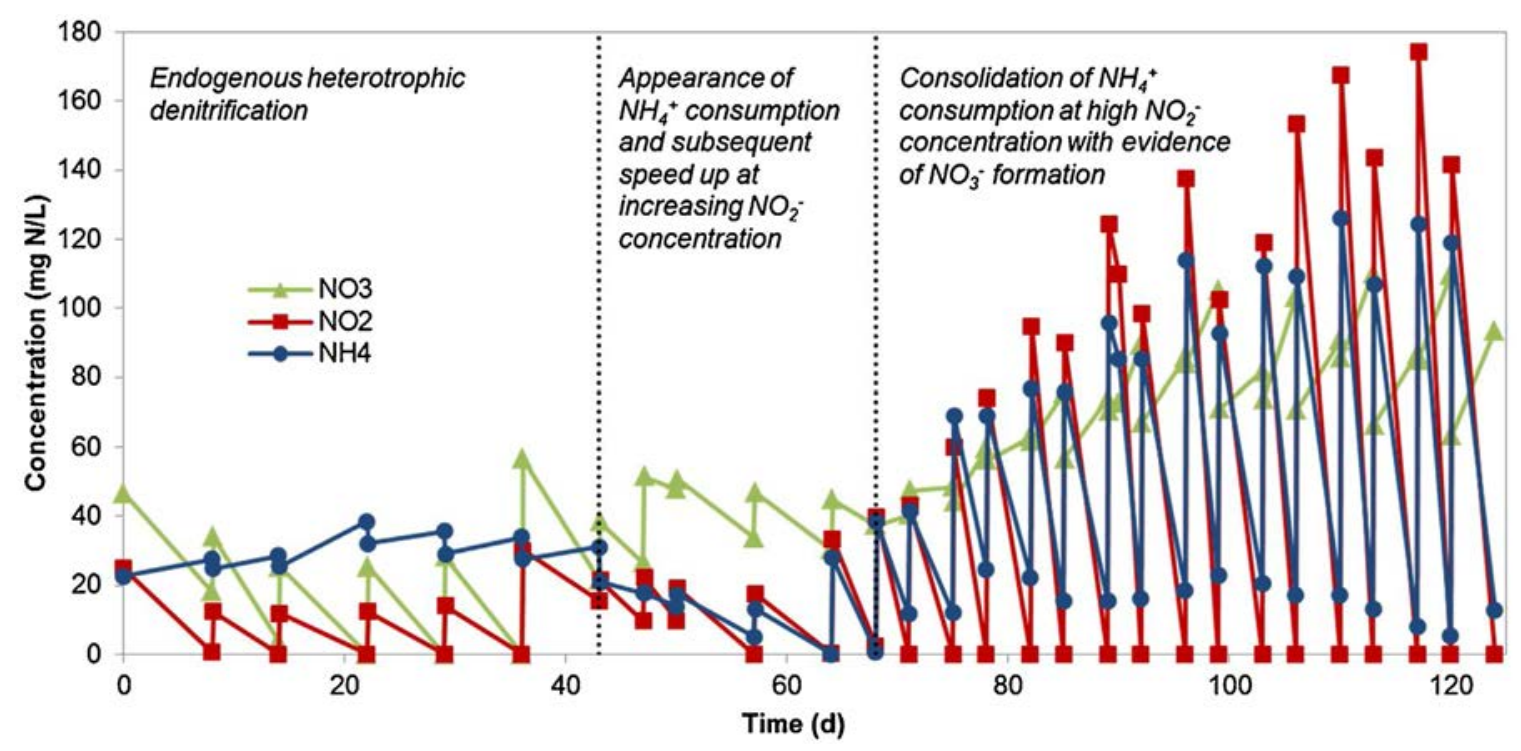

Fig. 1. Evolution of the N-species during the batch enrichment of anammox biomass (4 months).

quality and polyclonal sequence reads. Filtered sequences were analyzed using the QIIME pipeline (v1.8.0) (Caporaso et al., 2010). Sequences shorter than 200 bp or longer than $250 \mathrm{bp}$, chimeras, and singletons were removed from the dataset. Operational taxonomic units (OTUs) were subsequently defined using UPARSE implemented in USEARCH (v8.0.1623) (Edgar, 2013) at a 97\% similarity level. MOTHUR (v1.25.0) (Schloss et al., 2009) and SILVA (v119) (Quast et al., 2013) were used as the classifier tool and database for taxonomic association (with a minimum similarity threshold of $80 \%$ ), respectively.

\subsubsection{Statistical analysis}

The statistical analysis to assess the evolution of the microbial community structure was carried out through the non-metric multidimensional scaling (NMDS) method using the open-source software R (v3.2.3) (Venables et al., 2016) including the vegan package (v2.3-2) (Oksanen et al., 2016). The diversity indices Shannon-Weaver and Simpson, as well as the number of OTUs and equitability, were calculated for all samples.

\section{Results and discussion}

\subsection{Batch stage}

The batch enrichment developed significant anammox activity after 4 months (Fig. 1), which was measured, in terms of NCR, as $560 \pm 11 \mathrm{mg} \mathrm{N} /(\mathrm{Ld}$ ) (ammonium conversion rate of $222 \pm 2 \mathrm{mg}$ $\mathrm{NH}_{4}{ }^{+}-\mathrm{N} /(\mathrm{Ld})$ at a $\mathrm{NO}_{2}{ }^{-} / \mathrm{NH}_{4}{ }^{+}$reaction molar ratio of $1.53 \pm 0.03$ ) (Fig. 2). If referred to the VS content, this is equivalent to a specificNCR of $297 \pm 6 \mathrm{mg} \mathrm{N} /(\mathrm{g} \mathrm{VSd})$. At the end of the enrichment, the biomass still maintained the aspect of activated sludge and brownish colour, but tiny red granules could already be identified in the liquid bulk. Three main phases were observed throughout the enrichment period (Fig. 1): (Phase I) endogenous heterotrophic denitrification was the dominant process and ammonium may even slightly increase during incubation due to the hydrolysis of the remaining organic matter, (Phase II) appearance of ammonium consumption (detected after 43 days) and subsequent speed up at increasing concentrations of nitrite, and (Phase III) consolidation of ammonium consumption at high concentration of nitrite (attaining levels of $150 \mathrm{mg} \mathrm{NO}{ }^{-}-\mathrm{N} / \mathrm{L}$ ) under $\mathrm{NO}_{2}{ }^{-} / \mathrm{NH}_{4}{ }^{+}$reaction molar ratios approaching the value of 1.32 given in Eq. (1), and with evi-

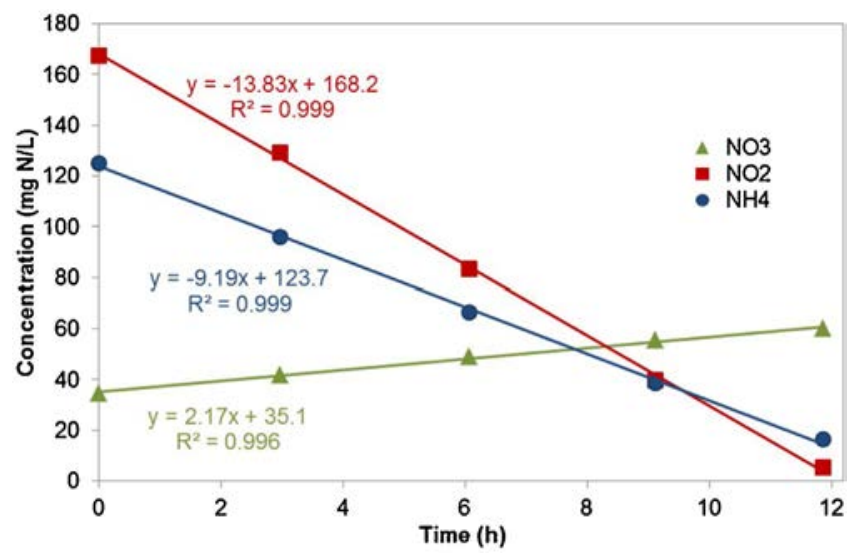

Fig. 2. Batch test carried out to assess the anammox activity after 4 months of enrichment.

dence of nitrate production. As previously reported (Connan et al., 2016; Uyanik et al., 2011), the nitrite supply strategy applied when targeting anammox biomass enrichment is of upmost importance. In this study, nitrite levels of $150 \mathrm{mg} \mathrm{NO}_{2}{ }^{-}-\mathrm{N} / \mathrm{L}$ were feasible without inhibition (this was corroborated by the linear evolution of the $\mathrm{N}$-forms observed in the final activity test, which was launched at nitrite concentrations slightly higher than $150 \mathrm{mg} \mathrm{NO}_{2}{ }^{-} \mathrm{N} / \mathrm{L}$; Fig. 2) although the enrichment was started using low concentrations of nitrite.

\subsection{Continuous stage}

\subsubsection{N-removal performance}

The suspended biomass with anaerobic ammonium-oxidizing activity was transferred into the upflow reactor. According to the corresponding reaction volumes, such handling implied an initial biomass dilution at a rate of about $1 / 8$. The upflow reactor was subsequently operated without interruption for a period of 400 days (Figs. 3 and 4, and Table 1). Two main phases can be identified throughout this long experimental period according to the availability of orthophosphate phosphorus in the mineral medium used for feeding the reactor (Section 2.4).

Phase I (90 days). The NLR was progressively increased (Fig. 3A) targeting from 111 to $332 \mathrm{mg} \mathrm{N} /(\mathrm{Ld})$ according to the nominal volu- 

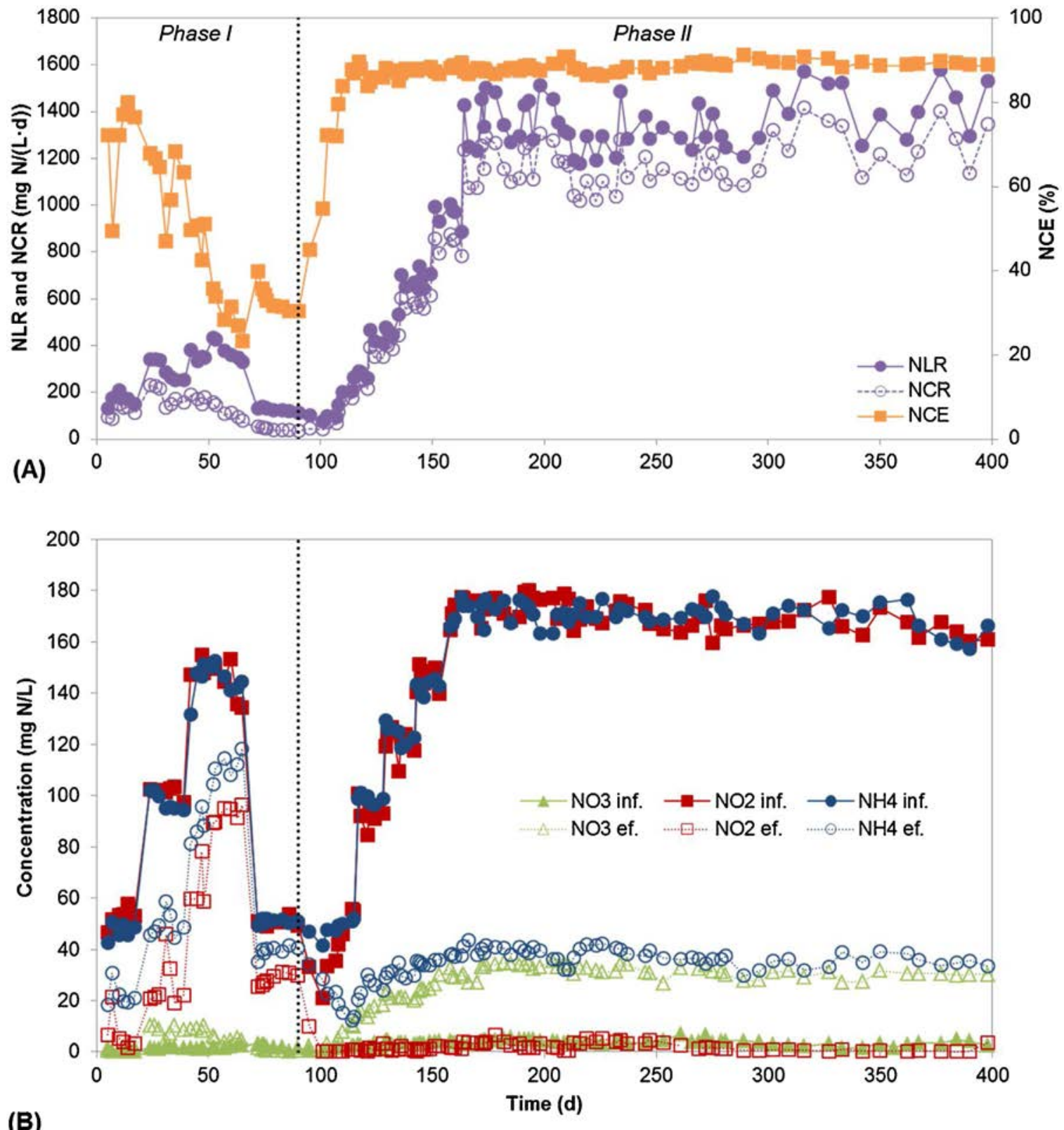

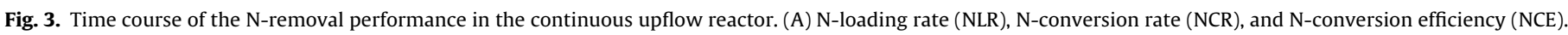
(B) Influent (inf.) and effluent (ef.) ammonium, nitrite, and nitrate concentrations.

Table 1

Summary of the operating conditions applied and performance for the upflow reactor.

\begin{tabular}{|c|c|c|c|}
\hline \multirow[t]{2}{*}{ Parameter $^{\mathrm{a}}$} & \multirow{2}{*}{$\begin{array}{l}\text { Phase I (90 d) } \\
-\end{array}$} & \multicolumn{2}{|c|}{ Phase II (310 d) } \\
\hline & & $73 d$ & $237 d$ \\
\hline HRT (h) & $18.1(2.6)^{b}$ & $22.4-7.2$ & $6.1(0.5)$ \\
\hline $\mathrm{NLR}(\mathrm{mg} \mathrm{N} /(\mathrm{Ld}))$ & $110-431$ & $73-1002$ & $1353(109)$ \\
\hline $\mathrm{NCR}(\mathrm{mg} \mathrm{N} /(\mathrm{Ld}))$ & $33-227$ & $39-870$ & $1183(100)$ \\
\hline $\operatorname{NCE}(\%)$ & $23-80$ & $45-89$ & $88(1)$ \\
\hline $\mathrm{NH}_{4}{ }^{+}$inf. $(\mathrm{mg} \mathrm{N} / \mathrm{L})$ & $43-152$ & $42-178$ & $170(5)$ \\
\hline $\mathrm{NO}_{2}{ }^{-}$inf. $(\mathrm{mg} \mathrm{N} / \mathrm{L})$ & $47-155$ & $21-178$ & $170(6)$ \\
\hline $\mathrm{NO}_{3}{ }^{-}$inf. $(\mathrm{mg} \mathrm{N} / \mathrm{L})$ & $1(1)$ & $3(1)$ & $4(1)$ \\
\hline $\mathrm{NH}_{4}{ }^{+}$ef. $(\mathrm{mg} \mathrm{N} / \mathrm{L})$ & $18-118$ & $12-38$ & $37(3)$ \\
\hline $\mathrm{NO}_{2}{ }^{-}$ef. $(\mathrm{mg} \mathrm{N} / \mathrm{L})$ & $2-96$ & $0-10$ & $2(2)$ \\
\hline $\mathrm{NO}_{3}-$ ef. $(\mathrm{mg} \mathrm{N} / \mathrm{L})$ & $0-10$ & $1-33$ & $32(2)$ \\
\hline $\mathrm{NO}_{2}-/ \mathrm{NH}_{4}{ }^{+}$reaction molar ratio & $1.70(0.28)$ & $1.34(0.12)$ & $1.27(0.06)$ \\
\hline $\mathrm{N}_{2} / \mathrm{NH}_{4}{ }^{+}$reaction molar ratio & $1.33(0.17)$ & $1.08(0.08)$ & $1.03(0.02)$ \\
\hline $\mathrm{NO}_{3}{ }^{-} / \mathrm{NH}_{4}{ }^{+}$reaction molar ratio & $0.05(0.10)$ & $0.18(0.05)$ & $0.21(0.02)$ \\
\hline
\end{tabular}

a Abbreviations: HRT, hydraulic residence time; NLR, N-loading rate; NCR, N-conversion rate; NCE, N-conversion efficiency; inf., influent; ef., effluent.

b Parameter values are provided according to the minimum-maximum range or as average (standard deviation in parentheses). 


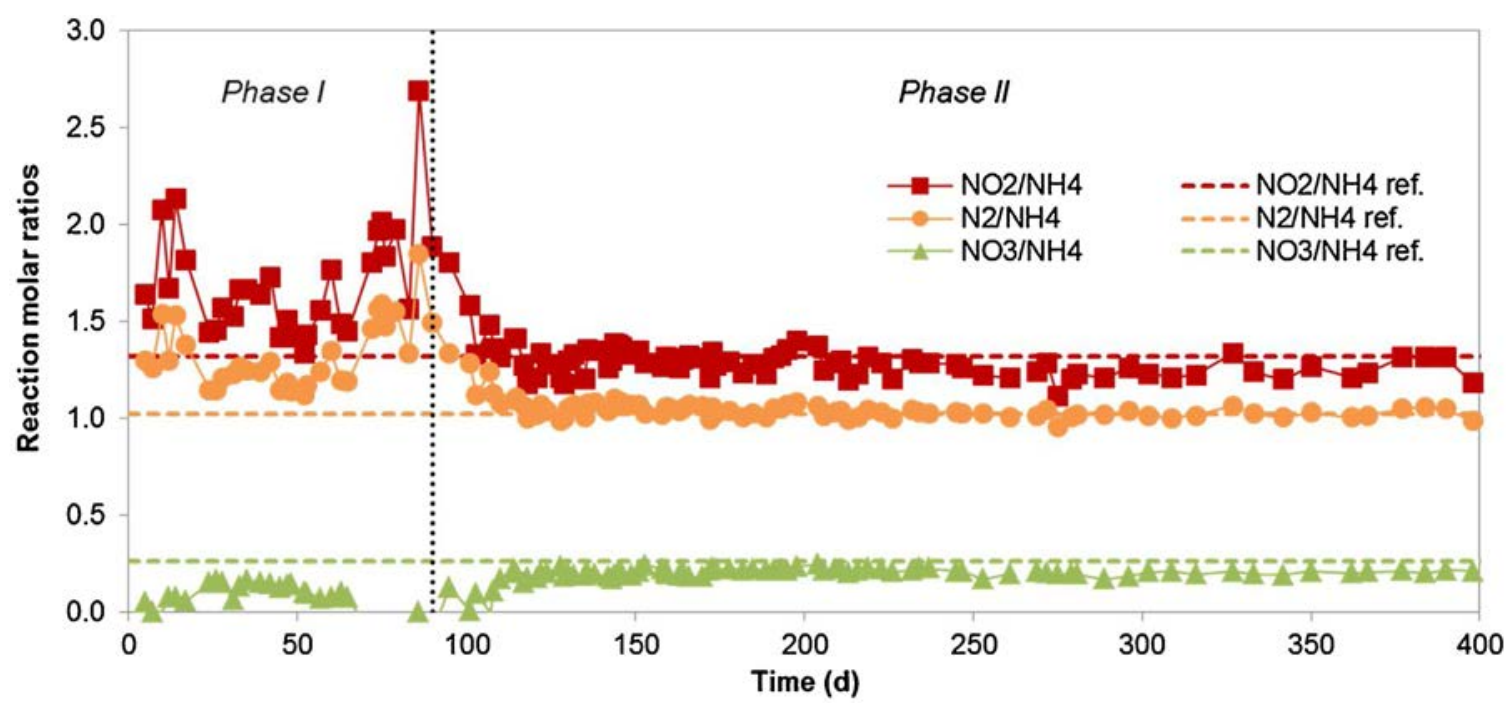

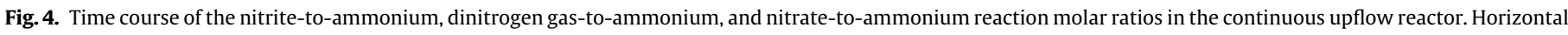
dashed lines indicate those reference (ref.) values provided in Eq. (1) (1.32, 1.02, and 0.26, respectively).

metric flow rate $(3 \mathrm{~mL} / \mathrm{min})$ and influent concentration $(50-150 \mathrm{mg}$ $\mathrm{NO}_{2}{ }^{-} \mathrm{N} / \mathrm{L}$ at a ratio of $1 \mathrm{~g} \mathrm{NO}_{2}^{-}-\mathrm{N} / \mathrm{g} \mathrm{NH}_{4}{ }^{+}-\mathrm{N}$ ). Taking into account the activity of the biomass measured at the end of the batch enrichment and the dilution rate applied, NCRs not lower than $70 \mathrm{mg} \mathrm{N} /(\mathrm{Ld})$ were expected. Satisfactory N-removal performance was observed during the first 10 days of operation with low nitrite (limiting substrate) concentration in the effluent (Fig. 3B). However, nitrite and ammonium started to accumulate in the reactor in the following days due to the lack of phosphorus in the feeding stream with the consequent decrease in the NCE. After 70 days of operation the nominal influent concentration of nitrite was returned to $50 \mathrm{mg} \mathrm{NO}_{2}{ }^{-} \mathrm{N} / \mathrm{L}$ but it did not imply the recovery of the system $(\mathrm{NCE}<40 \%)$. As depicted in Fig. 4, the reaction ratios during this phase did not match well those values given in Eq. (1), with higher values than expected for the $\mathrm{NO}_{2}{ }^{-} / \mathrm{NH}_{4}{ }^{+}$and $\mathrm{N}_{2} / \mathrm{NH}_{4}{ }^{+}$ reaction molar ratios but with lower values than expected for the $\mathrm{NO}_{3}{ }^{-} / \mathrm{NH}_{4}{ }^{+}$reaction molar ratio (which may be explained due to the coexistence of anammox and heterotrophic denitrification processes). Once arrived at this point, the problem with the phosphorus source had already been identified and the corresponding chemical used to prepare the mineral medium was replaced.

Phase II (310 days). In this second phase the NLR was progressively increased again (Fig. 3A). Particularly, the targeted loads ranged initially from 111 to $1034 \mathrm{mg} \mathrm{N} /(\mathrm{Ld})$ according to the nominal volumetric flow rate $(3-8 \mathrm{~mL} / \mathrm{min})$ and influent concentration (50-175 $\mathrm{mg} \mathrm{NO}_{2}{ }^{-} \mathrm{N} / \mathrm{L}$ at a ratio of $\left.1 \mathrm{~g} \mathrm{NO}_{2}{ }^{-}-\mathrm{N} / \mathrm{g} \mathrm{NH}_{4}{ }^{-}-\mathrm{N}\right)$. Fast recovery of the $\mathrm{N}$-removal (ammonium and nitrite) performance was observed, resulting in increased NCRs (maximum value of $870 \mathrm{mg} \mathrm{N} /(\mathrm{Ld})$ ) and NCEs (maximum value of $89 \%$ ). Nitrite was completely consumed ( $1 \pm 2 \mathrm{mg} \mathrm{N} / \mathrm{L}$ in the effluent), nitrate was again detected in the outlet (1-33 mg N/L) (Fig. 3B), and the reaction molar ratios evolved towards those given in Eq. (1) (Fig. 4). After 73 days of operation (total time: 163 days) the targeted NLR was further increased up to $1551 \mathrm{mg} \mathrm{N} /(\mathrm{Ld}$ ) according to a nominal volumetric flow rate of $12 \mathrm{~mL} / \mathrm{min}$ (maximum value planned for this study). Once arrived at this point, it was assumed that the anammox enrichment had been achieved successfully. The biomass growing at the bottom of the reactor and attached to the support material developed red colour. During the following 237 days the reactor run at an average NCR of $1183 \pm 100 \mathrm{mg} \mathrm{N} /(\mathrm{Ld})$ and NCE of $88 \pm 1 \%$ (Table 1 ) in order to continue the culture of the anammox biomass. During this time, the gas produced within the reactor was repeatedly analyzed aiming to detect $\mathrm{N}_{2} \mathrm{O}$. In this regard, $\mathrm{N}_{2} \mathrm{O}$ off-gas

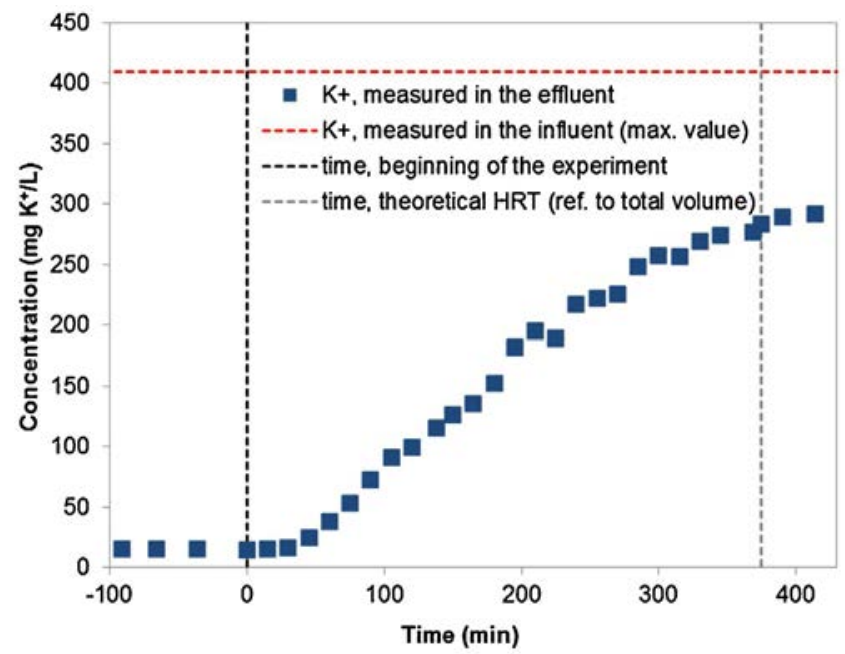

Fig. 5. Assessment of the liquid flow regime in the upflow reactor by introducing a step perturbation into the feed stream entering the reactor (replacement of the bicarbonate source in the mineral medium, from $\mathrm{NaHCO}_{3}$ to $\mathrm{KHCO}_{3}$ ) and subsequent monitoring of the concentration of $\mathrm{K}^{+}$in the outlet (day 266; volumetric flow rate of $12 \mathrm{~mL} / \mathrm{min}$ ). HRT, hydraulic residence time (here referred to the total liquid volume).

emissions never accounted for more than $0.2 \%$ of the applied $\mathrm{N}$ load, which is quite similar to the values reported by other authors such as Okabe et al. (2011) (0.1\% N-load in average) using similar bioreactor technology.

\subsubsection{Liquid flow regime assessment}

Despite the satisfactory $\mathrm{N}$-removal performance achieved, the existence of the support material, biomass growing, and rising gas bubbles within the reactor did result in a liquid flow regime far from the mixing patterns assumed in an ideal plug-flow reactor without axial mixing (where all the atoms of material leaving the reactor have been inside it for exactly the same amount of time (Fogler, 2006); i.e., the HRT). This was evidenced in a short-term experiment based on the introduction of a step perturbation into the system (Fig. 5); i.e., increase in the influent concentration of $\mathrm{K}^{+}$ (which does not take part in the anammox reaction). The mineral medium did not flow through the reactor uniformly, as it is shown by the temporal evolution of the concentration of $\mathrm{K}^{+}$in the outlet. Thus, at a time smaller than the HRT, the concentration of $\mathrm{K}^{+}$in 
the effluent started to increase (i.e., early exit of liquid), but at a time equal to the HRT, the concentration of $\mathrm{K}^{+}$in the effluent had not reached the inlet levels yet. This fact implies that, there were regions in the fixed-bed that offered little resistance to the flow, and as a result a major portion of the fluid channeled through this pathway. The molecules following this pathway did not spend as much time inside the reactor as those flowing through other regions offering high resistance to the flow.

The aforementioned non-ideal flow pattern did not significantly hinder the conversion of nitrite (limiting substrate in the mineral medium), and very low concentrations were measured in the outlet $\left(\sim 2 \mathrm{mg} \mathrm{NO}_{2}{ }^{-} \mathrm{N} / \mathrm{L}\right)$. Indeed, the NLR applied in this investigation was not pushed to maximum values -e.g., Tsushima et al. (2007) reported $\mathrm{N}$-removal rates as high as $26 \mathrm{~g} \mathrm{~N} /(\mathrm{Ld})$ in a similar upflow reactor- since main target was the effective culture of anammox biomass. In addition, uneven biomass accumulation was observed along the fixed-bed. Thus, the biomass especially grew attached at the bottom-end of the fabric material, partially evolving into granular biomass similarly as described elsewhere (Zhang et al., 2015). Such biomass distribution could favor the existence of a gradient for the vertical flow resistance as well as dead zones (in such case implying underestimation of the measured NCR). Alternative shapes and sizes of the non-woven carrier could also be considered for enhancing the culture process (Wang et al., 2016a). Anammox is an autotrophic process and, consequently, produces few amount of biomass. However, and according to this test, under long-term culture periods in upflow fixed-bed biofilm reactors it may still be necessary to periodically extract sludge from inside of the reactor in order to minimize the risk of clogging and to enhance the liquid flow.

\subsection{Microbial community characterisation}

Changes in the microbial community structure during the enrichment in batch (B) mode, and subsequently in the continuous (C) upflow reactor, were monitored using 16S rRNA high-throughput DNA sequencing. An external (E) sample coming from the upflow fixed-bed biofilm reactor running at the USDA-ARS laboratory (Vanotti et al., 2011) was also analyzed using the same methodology. After quality filtering, the number of sequences per sample ranged from 2648 (sample B3) to 20555 (sample B2) with an average for all the libraries of $11670 \pm 5593$ sequences per sample (13 samples in total). Coverage of all libraries, calculated after a systematic random depletion conducted to equalize the number of sequences per sample to that of the smallest library, was $\geq 95 \pm 3 \%$ (which is high enough to validate the subsequent analysis).

\subsubsection{Global evolution of the microbial community}

Microbial diversity throughout the entire experimental period (i.e., $\sim 18$ months) is assessed in Table 2 using the indices ShannonWeaver, Simpson and number of OTUs. Such diversity indices showed a systematic decrease during both the batch stage (i.e., reductions of $23.3 \%, 5.1 \%$, and $32.2 \%$, respectively, were confirmed between $\mathrm{B} 0$ and $\mathrm{B} 4$ ) and the continuous stage (i.e., index reductions of $29.8-40.4 \%, 11.1-22.2 \%$, and 34.5-68.3\%, respectively, were confirmed between CO and C3X). Particularly, for the batch stage, a sharp decrease occurred after 2 months of enrichment (e.g., the number of OTUs dropped about 50\% between B2 and B3). Indeed, in such time span it was expected an ecological transition linked to the changes in the dominant metabolic pathway; i.e., from denitrification to anammox (Fig. 1). Concerning the continuous stage, the index reductions were more variable, eventually depending on the sampling position within the reactor (e.g., the number of OTUs decreased between $34.5 \%$ and $68.3 \%$ ). According to this consideration, higher index reductions were found at the bottom side (where ammonium and nitrite concentrations were higher). Equitability also underwent systematic decrease during both stages; i.e., $22.2 \%$ and $28.6 \%$, respectively. Such data may imply concomitant disappearance of some species and larger segregation between the low and highly represented taxons (Magurran, 2004; Oksanen, 2016).

Relative evolution of the microbial community structure throughout the experimental period was also assessed using the NMDS method (Fig. 6). A progressive evolution of the microbial communities was observed for both batch and continuous stages. Regarding the batch stage, the dynamic conditions applied during the first 4 months induced a strong evolution of the microbial community, especially between B1 and B3 (transition from a denitrifying to an anammox ecosystem). After transferring the biomass to the continuous stage, the microbial community continued evolving. Initial lack of phosphorus in the feed stream resulted in a smaller relative change of the microbial community structure during the first 3.5 months ( $\mathrm{CO}$ vs. $\mathrm{C} 1 \mathrm{X}$ ) than in the following 3 months (C1X vs. C2X) after restoring the phosphorus supply. Concerning the next 7 months of culture (C2X vs. C3X), the microbial community structure still evolved, but at a lower rate. Fast stabilization of the microbial diversity in anammox reactors was reported by previous studies, even after perturbation episodes in the feed stream (Pereira et al., 2014). The external sample coming from the USDAARS anammox reactor (E) was also included in the NMDS analysis. Its microbial community remains appart from the final culture samples. The position of the different samples in the NMDS plot suggests that their vertical distribution is at least partly correlated with microbial diversity.

\subsubsection{Description of the microbial community}

Because of the large set of data, only OTUs containing more than $1 \%$ of the total sequences are considered. The proportion of OTUs excluded from the analysis by choosing this threshold progressively decreased during the experimental period; i.e., from $29 \%$ at initial time (B0) to $11 \%$ at the end of the batch stage (B4), and to $3 \%$ at the end of the continuous stage (C3X). Any of the currently known anammox genus was found within the excluded OTUs. Dominant microbial groups (OTUs with relative abundance $>1 \%$ of the total number of sequences) progressively evolved during both batch and continuous stages (Fig. 7). Such operational procedures could affect differently the evolution of the microbial community.

The phylum Proteobacteria, which is commonly retrieved in wastewater treatment ecosystems (Bertrand et al., 2011; Hu et al., 2012), was dominant in the activated sludge used as inoculum, but underwent a progressive decline, with a relative abundance decreasing from $36 \%$ (B0) to about $10 \%$ (C3X). Initially present as $\alpha-, \beta-$, and $\gamma$-Proteobacteria according to $7 \%, 15 \%$, and $13 \%$ of the total sequences, respectively, the experimental conditions applied favored the selection of genera belonging to the family Rhodocyclaceae (class $\beta$-proteobacteria). Thus, at the end of the experimental period, relative abundances for this family ranged from $2 \%$ (C3T) to $11 \%$ (C3B), while $\alpha$ - and $\gamma$-Proteobacteria represented less than $1 \%$ of the total community. The most frequent genus belonging to Rhodocyclaceae was related to the uncultured bacterium clone Dok59 (FJ710778), which has previously been retrieved from a long-term operated anammox biofilm reactor, and it is closely related to the denitrifying bacteria Denitratisoma oestradiolicum clone 20b_15 (KF810114, 99\% similarity). Such genus was also identified as the dominant proteobacterial genus in the external sample coming from the USDA-ARS anammox reactor (with relative abundance of $9 \%$ ).

The phyla Bacteroidetes (16\%), Chloroflexi (15\%), Actinobacteria (9\%), Acidobacteria (5\%), and Planctomycetes (5\%) were also abundant in the seeding sludge. Regarding Bacteroidetes, a progressive reduction in its relative abundance was observed (up to about $2 \%$ of the total sequences at the end of the experimental period). It appears that the provided conditions were not favorable for Bac- 
Table 2

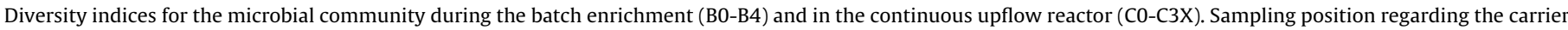
within the upflow reactor is identified with the letter "B" for bottom or " $T$ " for top. The external sample coming from USDA-ARS (E) is also included.

\begin{tabular}{|c|c|c|c|c|c|c|c|c|c|c|c|c|c|}
\hline \multirow{3}{*}{$\begin{array}{l}\text { Time (months) } \\
\text { Sample }\end{array}$} & \multicolumn{5}{|c|}{ Batch stage } & \multicolumn{8}{|c|}{ Continuous stage } \\
\hline & 0 & 1 & 2 & 3 & 4 & 0 & 3.5 & & 6.5 & & 13.5 & & USDA-ARS \\
\hline & B0 & B1 & B2 & B3 & B4 & $\mathrm{CO}$ & $\mathrm{C} 1 \mathrm{~T}$ & $\mathrm{C} 1 \mathrm{~B}$ & $\mathrm{C} 2 \mathrm{~T}$ & $\mathrm{C} 2 \mathrm{~B}$ & $\mathrm{C} 3 \mathrm{~T}$ & $\mathrm{C} 3 \mathrm{~B}$ & $\mathrm{E}$ \\
\hline Shannon-Weaver & 7.8 & 7.6 & 7.7 & 5.7 & 6.0 & 5.7 & 4.9 & 4.6 & 3.6 & 4.8 & 4.0 & 3.4 & 5.8 \\
\hline Simpson & 0.99 & 0.99 & 0.99 & 0.95 & 0.94 & 0.90 & 0.90 & 0.90 & 0.70 & 0.90 & 0.80 & 0.70 & 0.96 \\
\hline Number of OTUs & 552 & 515 & 576 & 271 & 374 & 319 & 192 & 154 & 147 & 207 & 209 & 101 & 231 \\
\hline Equitability & 0.9 & 0.8 & 0.8 & 0.7 & 0.7 & 0.7 & 0.6 & 0.6 & 0.5 & 0.6 & 0.5 & 0.5 & 0.7 \\
\hline
\end{tabular}

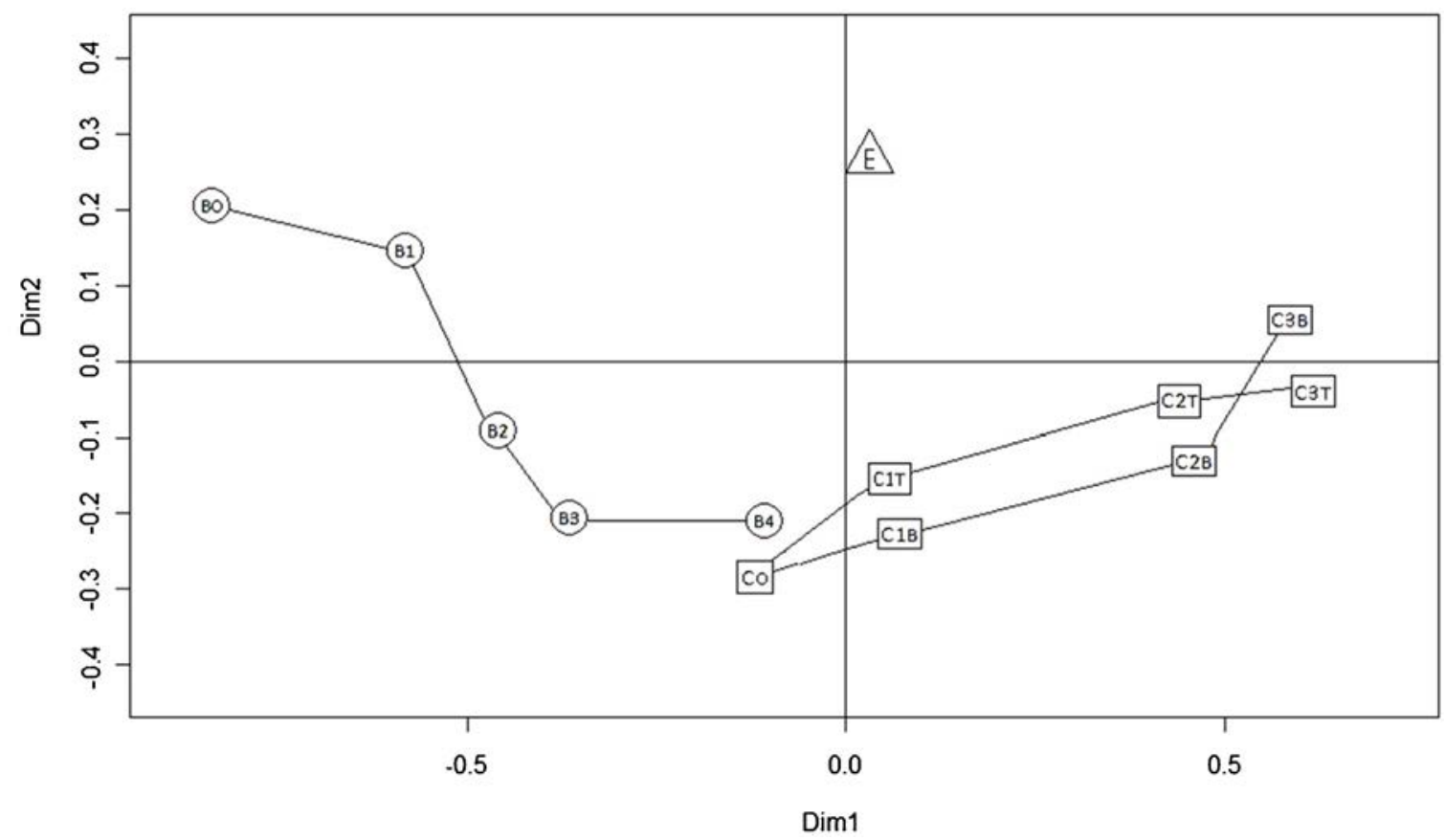

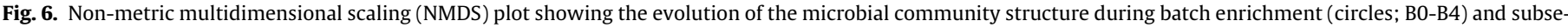

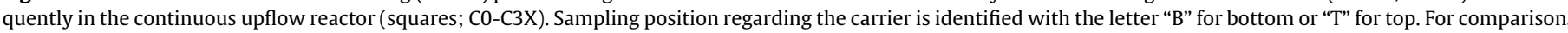
the external sample coming from USDA-ARS is also included (triangle; E).

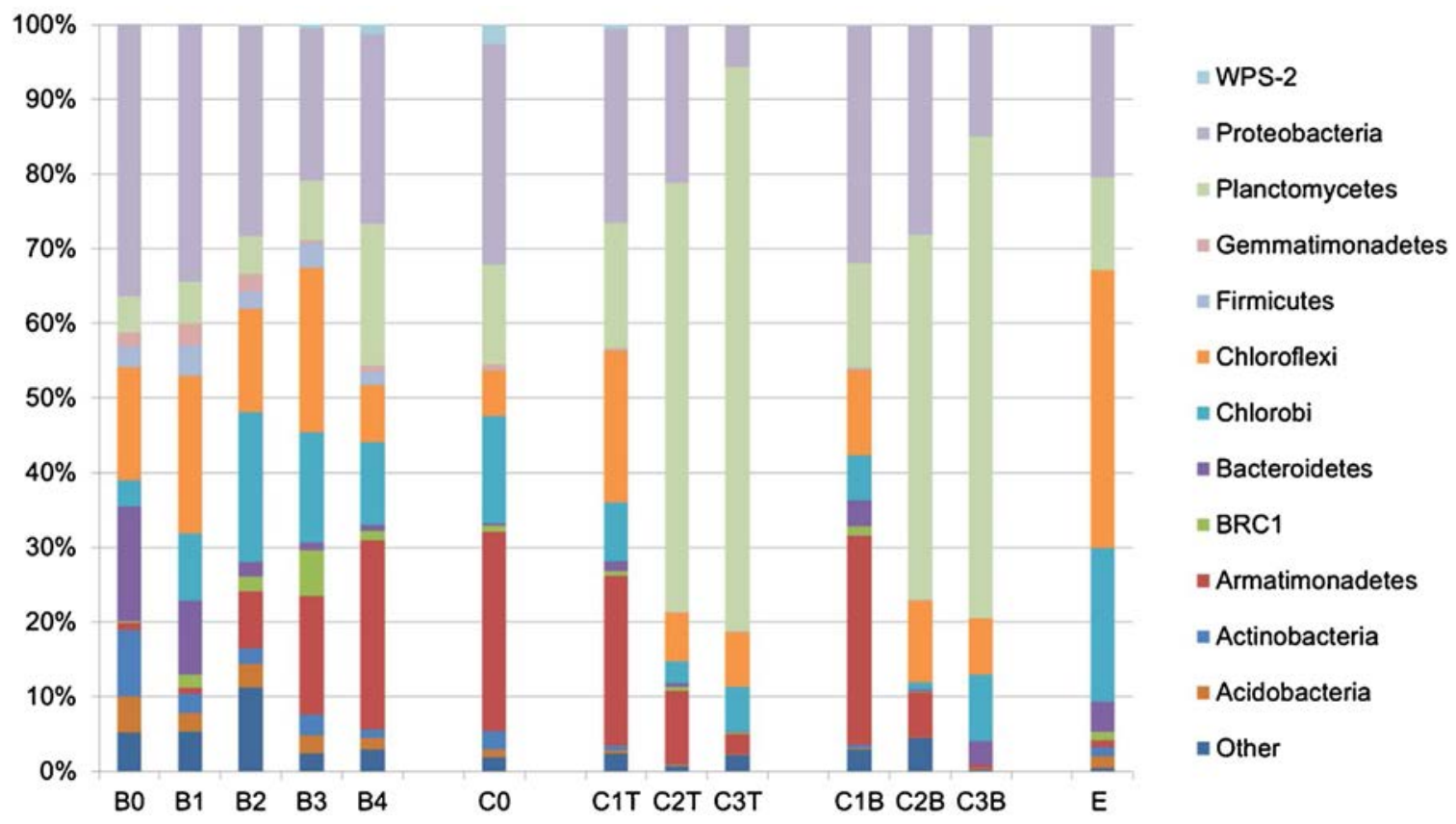

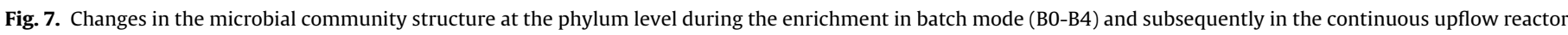

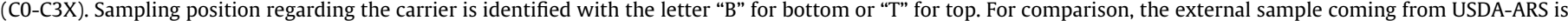
also included (E). Results are expressed as relative abundances (\% of the total number of sequences). 
teroidetes, mainly found in the seeding sludge as bacteria related to the family Saprospiraceae (which are known as aerobic and denitrifying chemoorganotrophs). Chloroflexi, which is composed of filamentous bacteria frequently present in activated sludge, was almost exclusively represented by genera belonging to the class Anaerolineae. The relative abundance of such class decreased from $12 \%$ to $7 \%$ at the end of the batch enrichment (B4). Similar abundance was found at the end of the continuous culture (C3X). Chloroflexi is usually present in anammox reactors and it has been suggested that they can grow using materials derived from decaying anammox bacterial cells (Kindaichi et al., 2012). In the external sample coming from the USDA-ARS anammox reactor such phylum reached a relative abundance as high as $37 \%$. Relative abundances for Actinobacteria and Acidobacteria declined rapidly during the batch enrichment reaching final values below $2 \%$ (B4). Such trend continued during the continuous stage and final percentages below $0.2 \%$ (C3X) were obtained. The same behavior was observed for the phyla Firmicutes and Gemmatimonadetes that were poorly represented in the initial sludge (3\% and $2 \%$, respectively, in B0).

Conversely, the batch stage promoted an increase in the relative abundance of Plantomycetes from 5\% (B0) to 19\% (B4) that further pursued in the continuous stage from $13 \%$ (CO) to about $70 \%$ (C3X). Interestingly, this phylum was initially represented in the seeding sludge by the family Pirellulaceae, and anammoxlike microorganisms were undetectable during the first 3 months of enrichment. Throughout incubation, the relative abundance of Pirellulaceae declined in favor of the anammox family Brocadiaceae. The percentages for this last family reached $17 \%$ of the total sequences for B4 and 57-75\% for C3X. The enriched species was Ca. Brocadia sinica which was the only anammox microorganism detected during the whole culture period except in one sample. Those experimental conditions applied for conducting the culture strongly prompted the selection of this species, that was certainly responsible for the observed anammox metabolism, and which has been proposed as an $r$-strategist (Ali and Okabe, 2015; Oshiki et al., 2011). The other aforementioned anammox species was identified as Ca. B. fulgida, and it was observed only in the sample C3B (relative abundance only was $0.5 \%$ of the total anammox sequences at this time). A much lower relative abundance of anammox-related sequences was identified for the external sample coming from the USDA-ARS anammox reactor (only $12 \%$ of the total microbial sequences). Here, the dominant species was Ca. B. fulgida that accounted for the $97 \%$ of the total anammox sequences, and to a lesser extent Ca. B. caroliniensis and Ca. B. sinica (accounting for $2 \%$ and $1 \%$ of the total anammox sequences, respectively).

Concerning other phyla less represented in the seeding sludge, the batch stage promoted Chlorobi, with relative abundances rising from $4 \%$ to $20 \%$ in 2 months, but it was followed by a decrease and stagnation at the end of the first stage and during the continuous stage (8\%). Those genera enriched during the batch stage mainly belonged to the photoautotrophic ranks C20 and OPB56 which subsequently disappeared during the continuous stage. Within the upflow reactor, Chlorobi was mostly represented by the non-phototrophic chemoheterotrophic family Ignavibacteriaceae (6\% of the total sequences, $100 \%$ similarity with uncultured clone KU000307). It is suggested that bacteria belonging to such family uses organic matter coming from other cells forming the biofilm. This is also supported by its high relative abundance in the USDA-ARS sample (19\% of the total sequences). Finally, the phylum Armatimonadetes showed a significant enrichment during the batch stage with a relative abundance increasing from $1 \%$ (B0) to $25 \%$ (B4). Conversely, the continuous stage promoted its disappearance with relative abundances decreasing from $27 \%$ (C0) to $2 \%$ (C3X). Recently identified organisms related to Armatimonadetes have been found in different natural environments and freshwater sediments (Tamaki et al., 2011; Yin et al., 2015).
The highly specific conditions applied to the biomass during this study (i.e., mild temperature, lack of oxygen, absence of organic compounds in the feeding, simultaneous exposure to ammonium and nitrite, and prevention to light exposure, among others) represent a significant shift in comparison to the environmental conditions existing in the inoculum's sampling site (municipal WWTP), and governed the evolution and selection of the microbial community. As a consequence, the microbial community of the seeding activated sludge underwent strong composition rearrangement. Initially primarily composed by Proteobacteria, Bacteroidetes, Chloroflexi, and Actinobacteria, with only $5 \%$ of Planctomycetes and any detectable anammox microbial group, it resulted in a biomass culture with $\sim 70 \%$ relative abundance of the anammox species Ca B. sinica, as well as up to $2-11 \%$ of Rhodocyclaceae (class $\beta$-Proteobacteria), $7-8 \%$ of Chloroflexi (dominated by family Anaerolineae), and 6-9\% of Chlorobi (dominated by family Ignavibacteriaceae). According to these findings, the particular conditions applied in our system favored the selection of not only anammox bacteria but also of other bacterial groups without anammox activity that could be involved either in competitive or symbiotic microbial relationships (Connan et al., 2016; Wang et al., 2016b). Such final microbial community composition is somehow different from the microbial community of the sample from the USDA-ARS anammox reactor which was primarily composed by Chloroflexi (37\%), Chlorobi (21\%), Proteobacteria (20\%), and Planctomycetes (12\%). The same families Rhodocyclaceae and Ignavibacteriaceae but different anammox Ca. Brocadia species were identified.

Indeed, high selective pressure through restrictive environmental trophic conditions has been widely reported to decrease microbial diversity and to favor the appearance of dominant species fitting the metabolic requirements, as expected in this study for the anammox bacteria (Connan et al., 2016; Costa et al., 2014; Isanta et al., 2015). On the other hand, when comparing the diversity indices for the anammox biomass here produced with those of the anammox biomass coming from the USDA-ARS anammox reactor, higher values were clearly found for the external sample (Table 2) although both biomasses were obtained from a continuous upflow reactor running during a long period ( $>1$ year) under very similar stable conditions. In this regard, some authors (Costa et al., 2014; Date et al., 2009) have reported that despite the long-term application of similar operational conditions in anammox reactors, differences may still exist in the microbial communities according to the biomass seeding source. The particular procedure followed for initial biomass enrichment, which was different in both cases (Connan et al., 2016; Vanotti et al., 2011), may also impact on the microbial community. The hydraulic performance of both reactors (affecting substrate concentration and biomass gradients within the reactor) and also the different conditions applied for storing the DNA samples are other factors that may play a role in such results.

\section{Conclusions}

A combined batch-continuous procedure for the mass culture of anammox biomass was described in detail. In the first stage, successful batch enrichment of anammox bacteria from activated sludge was achieved under a progressively increasing nitrite load (i.e., final measured NCR was $560 \pm 11 \mathrm{mg} \mathrm{N} /(\mathrm{Ld}$ ) after 120 days). Subsequently, and under an appropriate feeding regime, biomass culture was accomplished in the second stage consisting on a continuous upflow reactor packed with a fabric material to promote the attached growth of the biomass. A sustained NCR of $1183 \pm 100 \mathrm{mg} \mathrm{N} /(\mathrm{Ld})$ was reached according to the NLR applied. The upflow reactor was operated without interruption during 
400 days. The overall procedure resulted in the selection of a microbial community with up to $\sim 70 \%$ of the anammox species $C a$. $B$. sinica. Other significant coexisting microbial groups belonged to the family Rhodocyclaceae (class $\beta$-Proteobacteria) and the phyla Chloroflexi and Chlorobi.

\section{Conflict of interest}

The authors have declared no conflict of interest.

\section{Acknowledgements}

This work was supported by Rennes Métropole [Allocation d'Installation Scientifique (AIS) ref. 14C0509]. The authors are grateful to Chrystelle Bureau for technical assistance with microbial analyses and to the master's student Marina Moya-Espinosa for help with the operation of the upflow reactor. The external USDAARS sample was provided to Irstea through the Material Transfer Agreement (MTA) no. 10598.

\section{References}

Ali, M., Okabe, S., 2015. Anammox-based technologies for nitrogen removal: advances in process start-up and remaining issues. Chemosphere 141, 144-153, http://dx.doi.org/10.1016/j.chemosphere.2015.06.094.

Bae, H., Park, K.-S., Chung, Y.-C., Jung, J.-Y., 2010. Distribution of anammox bacteria in domestic WWTPs and their enrichments evaluated by real-time quantitative PCR. Process Biochem. 45, 323-334, http://dx.doi.org/10.1016/j.procbio.2009. 10.004 .

Bae, H., Choi, M., Lee, C., Chung, Y.-C., Yoo, Y.J., Lee, S., 2015. Enrichment of ANAMMOX bacteria from conventional activated sludge entrapped in poly(vinyl alcohol)/sodium alginate gel. Chem. Eng. J. 281, 531-540, http://dx. doi.org/10.1016/j.cej.2015.06.111.

Bertrand, J.-C., Caumette, P., Lebaron, P., Matheron, R., Normand, P., 2011. Écologie Microbienne: Microbiologie des Milieux Naturels et Anthropisés. Presses universitaires de Pau et des Pays de l'Adour, Pau, France (In French).

Caporaso, J.G., Kuczynski, J., Stombaugh, J., Bittinger, K., Bushman, F.D., Costello, E.K., Fierer, N., Gonzalez Peña, A., Goodrich, J.K., Gordon, J.I., Huttley, G.A., Kelley, S.T., Knights, D., Koenig, J.E., Ley, R.E., Lozupone, C.A., McDonald, D., Muegge, B.D., Pirrung, M., Reeder, J., Sevinsky, J.R., Turnbaugh, P.J., Walters, W.A., Widmann, J., Yatsunenko, T., Zaneveld, J., Knight, R., 2010. QIIME allows analysis of high-throughput community sequencing data. Nat. Methods 7 , 335-336, http://dx.doi.org/10.1038/nmeth.f.303.

Carvajal-Arroyo, J.M., Sun, W., Sierra-Alvarez, R., Field, J.A., 2013. Inhibition of anaerobic ammonium oxidizing (anammox) enrichment cultures by substrates, metabolites and common wastewater constituents. Chemosphere 91, 22-27, http://dx.doi.org/10.1016/j.chemosphere.2012.11.025.

Casagrande, C.G., Kunz, A., Soares, H.M., de Prá, M.C., Neto, G.F.S., 2011. Establishment of anammox process in sludge samples collected from swine wastewater treatment system. Eng. Agr.-Jaboticabal 31, 1170-1178, http://dx doi.org/10.1590/S0100-69162011000600014.

Connan, R., Dabert, P., Khalil, H., Bridoux, G., Béline, F., Magrí, A., 2016. Batch enrichment of anammox bacteria and study of the underlying microbial community dynamics. Chem. Eng. J. 297, 217-228, http://dx.doi.org/10.1016/j. cej.2016.03.154.

Costa, M.C.M.S., Carvalho, L., Leal, C.D., Dias, M.F., Martins, K.L., Garcia, G.B., Mancuelo, I.D., Hipólito, T., MacConell, E.F.A., Okada, D., Etchebehere, C. Chernicharo, C.A.L., Araujo, J.C., 2014. Impact of inocula and operating conditions on the microbial community structure of two anammox reactors. Environ. Technol. 35, 1811-1822, http://dx.doi.org/10.1080/09593330.2014. 883432.

Date, Y., Isaka, K., Ikuta, H., Sumino, T., Kaneko, N., Yoshie, S., Tsuneda, S., Inamori, Y., 2009. Microbial diversity of anammox bacteria enriched from different types of seed sludge in an anaerobic continuous-feeding cultivation reactor. J. Biosci. Bioeng. 107, 281-286, http://dx.doi.org/10.1016/j.jbiosc.2008.11.015.

de Almeida, N.M., Maalcke, W.J., Keltjens, J.T., Jetten, M.S.M., Kartal, B., 2011. Proteins and protein complexes involved in the biochemical reactions of anaerobic ammonium-oxidizing bacteria. Biochem. Soc. Trans. 39, 303-308, http://dx.doi.org/10.1042/BST0390303.

Edgar, R.C., 2013. UPARSE: highly accurate OTU sequences from microbial amplicon reads. Nat. Methods 10, 996-998, http://dx.doi.org/10.1038/nmeth.2604.

Egli, K., Bosshard, F., Werlen, C., Lais, P., Siegrist, H., Zehnder, A.J.B., van der Meer, J.R., 2003. Microbial composition and structure of a rotating biological contactor biofilm treating ammonium-rich wastewater without organic carbon. Microb. Ecol. 45, 419-432, http://dx.doi.org/10.1007/s00248-002 2037-5.

Fogler, H.S., 2006. Elements of Chemical Reaction Engineering, fourth ed. Pearson Education Inc., Upper Saddle River, NJ, USA.
Furukawa, K., Rouse, J.D., Yoshida, N., Hatanaka, H., 2003. Mass cultivation of anaerobic ammonium-oxidizing sludge using a novel nonwoven biomass carrier. J. Chem. Eng. Jpn. 36, 1163-1169, http://dx.doi.org/10.1252/jcej.36. 1163.

Hu, M., Wang, X., Wen, X., Xia, Y., 2012. Microbial community structures in different wastewater treatment plants as revealed by 454-pyrosequencing analysis. Bioresour. Technol. 117, 72-79, http://dx.doi.org/10.1016/j.biortech. 2012.04.061.

Ibrahim, M., Yusof, N., Yusoff, M.Z.M., Hassan, M.A., 2016. Enrichment of anaerobic ammonium oxidation (anammox) bacteria for short start-up of the anammox process: a review. Desalin. Water Treat. 57, 13958-13978, http://dx.doi.org/10. 1080/19443994.2015.1063009.

Isanta, E., Bezerra, T., Fernández, I., Suárez-Ojeda, M.E., Pérez, J., Carrera, J., 2015. Microbial community shifts on an anammox reactor after a temperature shock using 454-pyrosequencing analysis. Bioresour. Technol. 181, 207-213, http:// dx.doi.org/10.1016/j.biortech.2015.01.064.

Kartal, B., Rattray, J., van Niftrik, L.A., van de Vossenberg, J., Schmid, M.C., Webb, R.I., Schouten, S., Fuerst, J.A., Damsté, J.S., Jetten, M.S.M., Strous, M., 2007. Candidatus "Anammoxoglobus propionicus" a new propionate oxidizing species of anaerobic ammonium oxidizing bacteria. Syst. Appl. Microbiol. 30 39-49, http://dx.doi.org/10.1016/j.syapm.2006.03.004.

Kartal, B., Maalcke, W.J., de Almeida, N.M., Cirpus, I., Gloerich, J., Geerts, W., Op den Camp, H.J.M., Harhangi, H.R., Janssen-Megens, E.M., Francoijs, K.-J., Stunnenberg, H.G., Keltjens, J.T., Jetten, M.S.M., Strous, M., 2011. Molecular mechanism of anaerobic ammonium oxidation. Nature 479, 127-132, http:// dx.doi.org/10.1038/nature10453.

Khramenkov, S.V., Kozlov, M.N., Kevbrina, M.V., Dorofeev, A.G., Kazakova, E.A., Grachev, V.A., Kuznetsov, B.B., Polyakov, D.Y., Nikolaev, Y.A., 2013. A novel bacterium carrying out anaerobic ammonium oxidation in a reactor for biological treatment of the filtrate of wastewater fermented sludge. Microbiology 82, 628-636, http://dx.doi.org/10.1134/S002626171305007X.

Kindaichi, T., Yuri, S., Ozaki, N., Ohashi, A., 2012. Ecophysiological role and function of uncultured Chloroflexi in an anammox reactor. Water Sci. Technol. 66, 2556-2561, http://dx.doi.org/10.2166/wst.2012.479.

Kuypers, M.M.M., Sliekers, A.O., Lavik, G., Schmid, M., Jørgensen, B.B., Kuenen, J.G., Damsté, J.S.S., Strous, M., Jetten, M.S.M., 2003. Anaerobic ammonium oxidation by anammox bacteria in the Black Sea. Nature 422, 608-611, http://dx.doi.org/ 10.1038 /nature 01472 .

Lotti, T., Kleerebezem, R., Lubello, C., van Loosdrecht, M.C.M., 2014. Physiological and kinetic characterization of a suspended cell anammox culture. Water Res. 60, 1-14, http://dx.doi.org/10.1016/j.watres.2014.04.017.

Lotti, T., Kleerebezem, R., Abelleira-Pereira, J.M., Abbas, B., van Loosdrecht, M.C.M., 2015. Faster through training: the anammox case. Water Res. 81, 261-268, http://dx.doi.org/10.1016/j.watres.2015.06.001.

Ma, B., Wang, S., Cao, S., Miao, Y., Jia, F., Du, R., Peng, Y., 2016. Biological nitrogen removal from sewage via anammox: recent advances. Bioresour. Technol. 200, 981-990, http://dx.doi.org/10.1016/j.biortech.2015.10.074.

Magrí, A., Vanotti, M.B., Szögi, A.A., 2012a. Anammox sludge immobilized in polyvinyl alcohol (PVA) cryogel carriers. Bioresour. Technol. 114, 231-240, http://dx.doi.org/10.1016/j.biortech.2012.03.077.

Magrí, A., Vanotti, M.B., Szögi, A.A., Cantrell, K.B., 2012b. Partial nitritation of swine wastewater in view of its coupling with the anammox process. J. Environ. Qual. 41, 1989-2000, http://dx.doi.org/10.2134/jeq2012.0092.

Magrí, A., Béline, F., Dabert, P., 2013. Feasibility and interest of the anammox process as treatment alternative for anaerobic digester supernatants in manure processing -an overview. J. Environ. Manage. 131, 170-184, http://dx. doi.org/10.1016/j.jenvman.2013.09.021.

Magurran, A.E., 2004. Measuring Biological Diversity. Blackwell Science Ltd., UK.

Okabe, S., Oshiki, M., Takahashi, Y., Satoh, H., 2011. $\mathrm{N}_{2} \mathrm{O}$ emission from a partial nitrification-anammox process and identification of a key biological process of $\mathrm{N}_{2} \mathrm{O}$ emission from anammox granules. Water Res. 45, 6461-6470, http://dx. doi.org/10.1016/j.watres.2011.09.040.

Oksanen, J., Blanchet, F.G., Kindt, R., Legendre, P., Minchin, P.R., O'Hara, R.B., Simpson, G.L., Solymos, P., Stevens, M.H.H., Wagner, H., 2016. Package vegan, community ecology package, ver. 2. 3-4, https://cran.r-project.org/web/ packages/vegan/vegan.pdf. (Accessed 28 March 2016).

Oshiki, M., Shimokawa, M., Fujii, N., Satoh, H., Okabe, S., 2011. Physiological characteristics of the anaerobic ammonium-oxidizing bacterium 'Candidatus Brocadia sinica'. Microbiology 157, 1706-1713, http://dx.doi.org/10.1099/mic. $0.048595-0$.

Pereira, A.D., Leal, C.D., Dias, M.F., Etchebehere, C., Chernicharo, C.A.L., de Araújo, J.C., 2014. Effect of phenol on the nitrogen removal performance and microbial community structure and composition of an anammox reactor. Bioresour. Technol. 166, 103-111, http://dx.doi.org/10.1016/j.biortech.2014.05.043.

Poirier, S., Bize, A., Bureau, C., Bouchez, T., Chapleur, O., 2016a. Community shifts within anaerobic digestion microbiota facing phenol inhibition: towards early warning microbial indicators? Water Res. 100, 296-305, http://dx.doi.org/10. 1016/j.watres.2016.05.041.

Poirier, S., Quéméner, E.D.-L., Madigou, C., Bouchez, T., Chapleur, O., $2016 \mathrm{~b}$. Anaerobic digestion of biowaste under extreme ammonia concentration identification of key microbial phylotypes. Bioresour. Technol. 207, 92-101, http://dx.doi.org/10.1016/j.biortech.2016.01.124.

Quan, Z.-X., Rhee, S.-K., Zuo, J.-E., Yang, Y., Bae, J.-W., Park, J.R., Lee, S.-T., Park, Y.-H., 2008. Diversity of ammonium-oxidizing bacteria in a granular sludge anaerobic ammonium-oxidizing (anammox) reactor. Environ. Microbiol. 10, 3130-3139, http://dx.doi.org/10.1111/j.1462-2920.2008.01642.x. 
Quast, C., Pruesse, E., Yilmaz, P., Gerken, J., Schweer, T., Yarza, P., Peplies, J., Glöckner, F.O., 2013. The SILVA ribosomal RNA gene database project: improved data processing and web-based tools. Nucleic Acids Res. 41 D590-D596, http://dx.doi.org/10.1093/nar/gks1219.

Schloss, P.D., Westcott, S.L., Ryabin, T., Hall, J.R., Hartmann, M., Hollister, E.B., Lesniewski, R.A., Oakley, B.B., Parks, D.H., Robinson, C.J., Sahl, J.W., Stres, B., Thallinger, G.G., Van Horn, D.J., Weber, C.F., 2009. Introducing mothur: open-source, platform-independent, community-supported software fo describing and comparing microbial communities. Appl. Environ. Microbiol. 75, 7537-7541, http://dx.doi.org/10.1128/AEM.01541-09.

Schmid, M., Twachtmann, U., Klein, M., Strous, M., Juretschko, S., Jetten, M., Metzger, J.W., Schleifer, K.-H., Wagner, M., 2000. Molecular evidence for genus level diversity of bacteria capable of catalyzing anaerobic ammonium oxidation. Syst. Appl. Microbiol. 23, 93-106, http://dx.doi.org/10.1016/S07232020(00)80050-8.

Siegrist, H., Salzgeber, D., Eugster, J., Joss, A., 2008. Anammox brings WWTP closer to energy autarky due to increased biogas production and reduced aeration energy for N-removal. Water Sci. Technol. 57, 383-388, http://dx.doi.org/10. 2166/wst.2008.048.

Strous, M., Heijnen, J.J., Kuenen, J.G., Jetten, M.S.M., 1998. The sequencing batch reactor as a powerful tool for the study of slowly growing anaerobic ammonium-oxidizing microorganisms. Appl. Microbiol. Biotechnol. 50, 589-596, http://dx.doi.org/10.1007/s002530051340.

Strous, M., Fuerst, J.A., Kramer, E.H.M., Logemann, S., Muyzer, G., van de Pas-Schoonen, K.T., Webb, R., Kuenen, J.G., Jetten, M.S.M., 1999. Missing lithotroph identified as new planctomycete. Nature 400, 446-449, http://dx doi.org/10.1038/22749.

Tamaki, H., Tanaka, Y., Matsuzawa, H., Muramatsu, M., Meng, X.-Y., Hanada, S. Mori, K., Kamagata, Y., 2011. Armatimonas rosea gen. nov., sp. nov., of a novel bacterial phylum, Armatimonadetes phyl. nov., formally called the candidate phylum OP10. Int. J. Syst. Evol. Microbiol. 61, 1442-1447, http://dx.doi.org/10. 1099/ijs.0.025643-0.

Tsushima, I., Ogasawara, Y., Kindaichi, T., Satoh, H., Okabe, S., 2007. Development of high-rate anaerobic ammonium-oxidizing (anammox) biofilm reactors. Water Res. 41, 1623-1634, http://dx.doi.org/10.1016/j.watres.2007.01.050.

Uyanik, S., Bekmezci, O.K., Yurtsever, A., 2011. Strategies for successful ANAMMOX enrichment at laboratory scale. Clean-Soil Air Water 39, 653-657, http://dx. doi.org/10.1002/clen.201000591.

Van Hulle, S.W.H., Vandeweyer, H.J.P., Meesschaert, B.D., Vanrolleghem, P.A Dejans, P., Dumoulin, A., 2010. Engineering aspects and practical application of autotrophic nitrogen removal from nitrogen rich streams. Chem. Eng. J. 162, 1-20, http://dx.doi.org/10.1016/j.cej.2010.05.037. van Niftrik, L., Jetten, M.S.M., 2012. Anaerobic ammonium-oxidizing bacteria: unique microorganisms with exceptional properties. Microbiol. Mol. Biol. Rev. 76, 585-596, http://dx.doi.org/10.1128/MMBR.05025-11.

Vanotti, M., Fujii, T., Szögi, A., Rothrock, M., Garcia, M.C., Kunz, A., Magrí, A. Furukawa, K., 2011. Experiences with anammox in the USA: isolation, preservation and treatment performance of Brocadia caroliniensis. In: Proc. 1st International Anammox Symposium (IANAS 2011), Kumamoto University, Japan, pp. 99-106.

Venables, W.N., Smith, D.M., The R Core Team, 2016. An Introduction to R, Notes on R: a Programming Environment for Data Analysis and Graphics. Ver. 3.2.4, https://cran.r-project.org/doc/manuals/r-release/R-intro.pdf. (Accessed 28 March 2016).

Wang, Y., Qian, P.-Y., 2009. Conservative fragments in bacterial 16S rRNA genes and primer design for $16 \mathrm{~S}$ ribosomal DNA amplicons in metagenomic studies. PLoS One 4, e7401, http://dx.doi.org/10.1371/journal.pone.0007401.

Wang, T., Zhang, H., Yang, F., Liu, S., Fu, Z., Chen, H., 2009. Start-up of the anammox process from the conventional activated sludge in a membrane bioreactor. Bioresour. Technol. 100, 2501-2506, http://dx.doi.org/10.1016/j.biortech.2008. 12.011.

Wang, T., Zhang, H., Yang, F., 2016a. Performance of Anammox process and low-oxygen adaptability of Anammox biofilms in a FBR with small ring non-woven carriers. Ecol. Eng. 86, 126-134, http://dx.doi.org/10.1016/j. ecoleng.2015.11.025.

Wang, Y., Hu, X., Jiang, B., Song, Z., Ma, Y., 2016b. Symbiotic relationship analysis of predominant bacteria in a lab-scale anammox UASB bioreactor. Environ. Sci. Pollut. Res. 23, 7615-7626, http://dx.doi.org/10.1007/s11356-015-6016-Z.

Xiong, L., Wang, Y.-Y., Tang, C.-J., Chai, L.-Y., Xu, K.-Q., Song, Y.-X., Ali, M., Zheng, P., 2013. Start-up characteristics of a granule-based anammox UASB reactor seeded with anaerobic granular sludge. Biomed Res. Int., http://dx.doi.org/10. 1155/2013/396487 (Article ID 396487).

Yasuda, T., Waki, M., Yoshinaga, I., Amano, T., Suzuki, K., Tanaka, Y., Yamagishi, T., Suwa, Y., 2011. Evidence of exponential growth of an anammox population in an anaerobic batch culture. Microbes Environ. 26, 266-269, http://dx.doi.org/ 10.1264/jsme2.ME10181.

Yin, H., Niu, J., Ren, Y., Cong, J., Zhang, X., Fan, F., Xiao, Y., Zhang, X., Deng, J., Xie, M. He, Z., Zhou, J., Liang, Y., Liu, X., 2015. An integrated insight into the response of sedimentary microbial communities to heavy metal contamination. Sci. Rep. 5 , 14266, http://dx.doi.org/10.1038/srep14266.

Zhang, L., Liu, M., Zhang, S., Yang, Y., Peng, Y., 2015. Integrated fixed-biofilm activated sludge reactor as a powerful tool to enrich anammox biofilm and granular sludge. Chemosphere 140, 114-118, http://dx.doi.org/10.1016/j. chemosphere.2015.02.001. 